\title{
BMJ Open Prehospital delay and its associated psychosocial factors in patients presenting with acute appendicitis in a southwestern city in China: a single- centre prospective observational study
}

Jian Li, ${ }^{\ominus}$ Run Xu, Dengmin Hu, Yao Zhang, Tuping Gong, Xuelian Wu

To cite: Li J, Xu R, Hu D, et al. Prehospital delay and its associated psychosocial factors in patients presenting with acute appendicitis in a southwestern city in China: a single-centre prospective observational study. BMJ Open 2019;9:e023491. doi:10.1136/ bmjopen-2018-023491

- Prepublication history for this paper is available online. To view these files, please visit the journal online (http://dx.doi org/10.1136/bmjopen-2018023491).

Received 9 April 2018 Revised 5 December 2018 Accepted 16 May 2019
D) Check for updates

(c) Author(s) (or their employer(s)) 2019. Re-use permitted under CC BY-NC. No commercial re-use. See rights and permissions. Published by BMJ.

Department of General Surgery, the Third People's Hospital of Mianyang Sichuan Mental Health Center, Mianyang, China

Correspondence to

Dr Jian Li; 654747973@qq.com

\section{ABSTRACT}

Objective Prehospital delay is common among patients with acute appendicitis. The aim of this study was to measure the association of a wide range of psychosocial factors with the prehospital delay among adult patients with acute appendicitis in a southwestern city in China. Methods Sociodemographic, clinical, cognitive and psychosocial factors were collected from 421 adult patients with acute appendicitis from November 2016 to December 2017. In addition, factors associated with prehospital delay were determined by binary logistic regression, after adjusting for selected potentially confounding factors.

Results Only 179 (42.5\%) of the 421 patients were transferred to the hospital within 24 hours; the mean prehospital delay was 27.68 hours with a median of 26 hours, while the mean in-hospital delay was 5.16 hours with a median of 5 hours. In the logistic regression analyses, eight variables or subvariables were found to be associated with prehospital delay $>24$ hours.

Conclusion Delayed presentation for acute appendicitis was associated with older age, living alone, a lack of knowledge of the disease, low social support, an unstable introvert personality trait and negative coping style, intensity of the pain and the symptoms occurring on a workday. A better understanding of the association between psychosocial factors and prehospital delay can help identify patients with acute appendicitis at risk of prehospital delay and lead to the establishment of an effective campaign to promote hospital visits when the symptoms are noticed.

\section{BACKGROUND}

Acute appendicitis has been one of the most common intra-abdominal conditions with a $9.0 \%$ lifetime cumulative incidence rate, and appendectomy is the most frequently performed emergency operation by general surgeons worldwide. ${ }^{1}$ Despite significant advancements in diagnosis and treatment, the incidence of complicated acute appendicitis, including gangrenous or perforated appendicitis, remains considerably
Strengths and limitations of this study

- We were the first to test the association between psychosocial factors and prehospital delay in patients with acute appendicitis.

- Numerous factors may affect prehospital delay among patients with acute appendicitis, and the factors can confound each other; therefore, we considered sociodemographic characteristics, clinical factors, cognitive factors and psychosocial factors.

- We used a questionnaire to determine the psychosocial factors; participants' answers were subject to mistakes in recollection and other errors.

- The present study was conducted in a single centre; whether the present findings apply to other populations with different economic and cultural conditions is unknown.

high $(28 \%-29 \%),{ }^{2} 3$ and the postoperative morbidity rates remain between $9 \%$ and $18 \%{ }^{4}$

A time-honoured notion that the 'goal should be to accelerate diagnosis and to operate before perforation occurs' was based on the assumption that over time an inflamed appendix will likely progress to perforation. ${ }^{56}$ However, the notion has been challenged for both children and adults by many studies in recent years. To avoid disrupting operating room schedules and to reduce technical errors associated with sleep deprivation and fatigue, for uncomplicated acute appendicitis cases that present after hours, it was shown to be safe to delay operations until the next morning. ${ }^{78}$ Moreover, other reports suggested that spontaneous resolution was common in patients with low-grade appendicitis and that acute appendicitis could be managed with a semielective strategy after antibiotics therapy has been initiated; therefore, operation may 
not be the first choice in these instances, which further confused the issue. ${ }^{9-13}$

However, there are some pitfalls in these studies that limit the applicability of their results; an obvious error is to compare differences in the proportions with perforation or morbidity between groups with short and long delays regardless of bias in the characteristics of patients. ${ }^{14}$ In addition, conservative treatment may result in a high risk of recurrence, which may be problematic in elderly patients or pregnant women, and an increased financial burden results from repeated treatment. On the other hand, many studies have found a positive association between the time interval and the risk of perforation; a long delay until the operation results in complicated appendicitis, and as a consequence, also results in high postoperative morbidity. ${ }^{15-19}$

In fact, there are no essential differences between the two conclusions. The former studies focused on 'uncomplicated' acute appendicitis cases and their hospital-related delay, and the latter studies were mainly concerned with the total delay or prehospital delay. It seems that the prehospital delay played a more important role in the course of appendicitis. Therefore, we argue that there is no benefit to determining how long a delay before appendectomy is safe, but it would be useful to determine and avoid the contributors that can cause prehospital delay in patients with acute appendicitis. Therefore, the aim of this study was to measure the association of a wide range of psychosocial factors with the prehospital delay among adult patients with acute appendicitis in a southwestern city in China.

\section{METHODS}

\section{Settings and sampling}

This study was conducted on 421 adult patients with acute appendicitis from November 2016 to December 2017. The participants were newly diagnosed at the Third Hospital of Mianyang, which provides medical services for approximately 560 thousand people in a southwestern city in China. An initial interview was conducted with each patient to determine whether he/she met the inclusion criteria. A priori sample size calculation was performed with a level at 0.05 of $\alpha_{2 \text {-tailed }}$ and 0.20 of $\beta_{\text {2-tailed }}$.

\section{Inclusion and exclusion criteria}

We selected patients older than 18 years of age who sought the first medical assistance at our hospital, and the patients themselves or their caregivers agreed to participate in the study and completed the questionnaire. Patients who underwent an elective appendectomy after conservative treatment because of acute appendicitis or a sudden appendectomy during other intra-abdominal operations, whose diagnosis was confirmed by another hospital and who could not give sufficient information, were excluded.

\section{Data collection}

All investigators were trained before they were assigned to collect data. The data were obtained from the patients' hospital records and from a face-to-face survey, which was completed during the study period while the patients were visiting the hospital. Before the start of each interview, we confirmed that this would not interfere with the examination and treatment of patients.

\section{Demographic characteristics}

Data for age, sex, marital status, education level, occupation, monthly income, place of residence, living alone or with others, distance from home to hospital, insurance status and history of appendicitis among acquaintances were obtained during an interview using a questionnaire that was pretested and modified prior to final data collection was done. Age was categorised as 18-39, 40-59 and $\geq 60$ years of age. Marital status was categorised as unmarried, married and divorced/widowed. Educational level was classified as no formal schooling, primary or junior/middle school, and high school and above. Occupation was classified as unemployed, physical labour and non-physical labour. Monthly income was categorised as $<¥ 2000$, ¥2000-5000 and $>¥ 5000$. Place of residence was classified as rural, town and city. History of appendicitis among acquaintances required that the patient had experienced the process of diagnosis and treatment of acute appendicitis in one or more acquaintances.

\section{Clinical information}

Clinical information, including migrating pain, fever, vomiting, diarrhoea, right lower quadrant (RLQ) rebound tenderness, white blood cell count, neutrophil percentage, C-reactive protein, type of appendicitis, incarcerated by faecal stone, time of symptom onset and hospital arrival, time of operation room arrival, symptoms occurred on a workday or weekend (including a national legal holiday), and night-time or daytime symptom onset were obtained from the electronic medical records. Type of appendicitis was divided into two groups: complicated appendicitis (including gangrenous or perforated appendicitis, periappendiceal abscess) and uncomplicated appendicitis (including simple or suppurative/phlegmonous appendicitis). The intensity of pain was rated by patients at the time of admission using the Numerical Rating Scale, with values between 0 and $10^{20}$; we categorised scores of 1-3 as 'mild pain', 4-6 as 'moderate pain' and $7-10$ as 'severe pain'.

\section{Eysenck personality questionnaire-revised short scale for Chinese}

Personality traits were measured using the neuroticism scale (EPQ-N) and the extroversion scale (EPQ-E) of the Eysenck Personality Questionnaire-Revised Short Scale for Chinese (EPQ-RSC).$^{21}$ The EPQ-RSC has been used in early studies, and its reliability and validity as a measure of personality traits in China have been well documented. ${ }^{22} 23$ The total score for the extraversion subscale indicates introversion when it is less than 43.3, intermediate when it is from 43.3 to 56.7 and extraversion when it is greater than 56.7. For the neuroticism subscale, a total score of less than 43.3 defines emotional stability, whereas a total 
score from 43.3 to 56.7 defines intermediate and a total score greater than 56.7 defines emotional instability. ${ }^{23} \mathrm{In}$ this study, we classified five personality traits as follows: stable introverts (both EPQ-N and EPQ-E scores <43.2), stable extroverts (EPQ-N scores <43.2, EPQ-E scores $>56.7$ ), unstable extroverts (both EPQ-N and EPQ-E scores $>56.7$ ), unstable introverts (EPQ-N scores $>56.7$, EPQ-E scores $<43.2$ ) and transitional personality (others not captured in the above four categories). ${ }^{24}$ In this study, Cronbach's $\alpha$ was 0.812 and 0.797 for the extraversion and neuroticism subscales, respectively.

\section{Perceived social support scale}

Social support from family, friends and significant others was evaluated using the Perceived Social Support Scale (PSSS), which consists of 12 items ${ }^{25}$; it has good reliability and validity in various samples and has been used in China. ${ }^{26}{ }^{27}$ A higher score of $61-84$ was defined as good social support, $37-60$ as moderate social support and 12-36 as poor social support. ${ }^{28}$ The Cronbach's $\alpha$ for PSSS was 0.823 in this study.

\section{Trait coping style questionnaire}

Coping strategy was measured with the Chinese version of the Trait Coping Style Questionnaire (TCSQ), which has been widely used to measure patients' style of coping with life events. ${ }^{29}$ It is a 20 -item questionnaire designed to assess two types of coping strategies: positive coping refers to individuals who tend to deal with problems in a positive way and are able to quickly forget unpleasant aspects; negative coping refers to the tendency to use negative coping methods to deal with problems and vent frustrations to other people. Response scores for each question range from 1 to 5 . Higher total scores for each dimension indicated frequent usage of this type of coping. Previous studies have found TCSQ to have high reliability and validity as a measure of coping style in China. ${ }^{30}$ In this study, the internal consistency coefficients of the subscales were $\alpha=0.845$ (positive coping) and $\alpha=0.871$ (negative coping).

\section{Definition of delay}

Prehospital delay was defined as the time interval from when the first symptom was noticed until hospital arrival. In-hospital delay was defined as the time interval from hospital arrival to operating room arrival. Total delay was the sum of the former two times. For patients who did not undergo appendectomy, total delay was equal to prehospital delay. According to the recommendation of the World Emergency Surgery Association and the research results of Saar $e t a l,{ }^{31}{ }^{32}$ the patients were classified into two groups on the basis of prehospital delay: $\leq 24$ hours (no delay group) and $>24$ hours (delay group).

\section{Patient and public involvement}

Patients and the public were not involved in the design of the study. A summary of the main results will be made available to study participants on request. Participants will be acknowledged and thanked for their contributions during the publication and distribution of the results.

\section{Statistical analysis}

To ensure accuracy, the data were entered into an Excel database by two trained researchers after all the surveys were completed. Percentages (\%) or numbers (n) were provided for categorical variables; means and standard deviations (means \pm SD) were provided for continuous variables following a normal distribution, while medians and the IQRs were provided for continuous variables that did not follow a normal distribution. The normal distributions of the continuous variables were verified using K-S tests. As an initial step, significant differences between groups among all variables were determined using the Pearson $\chi^{2}$ test, Mann-Whitney $U$ test or independent samples t-test. Then, a binary logistic regression was performed to identify factors associated with the odds of a delay of longer than 24 hours in seeking medical assistance. Given the high number of variables under investigation and to balance the risk for type I and type II errors, only the variables in the initial step that were significantly different between the two groups at an alpha level of 0.05 could be entered into the binary logistic regression model. All statistical calculations were performed using IBM SPSS Statistics V.19.0 (IBM, Armonk, New York, USA). For all statistical analyses, a significance level of two-sided $p<0.05$ was assumed.

\section{RESULTS}

From November 2016 to December 2017, a total of 562 patients received a diagnosis of acute appendicitis in the Third Hospital of Mianyang, of whom 421 patients met the inclusion criteria; 42 patients were younger than 18 years, 52 patients were diagnosed in other hospitals before presentation to our emergency department and 47 patients refused to participate or could not give sufficient information were excluded. The patients studied had a mean age of 47.41 years $(\mathrm{SD}=18.89)$ and a median age of 44 years, and the peak age category was 31-65 years. The majority, $242(57.5 \%)$ patients, were delayed by more than 24 hours, while only $179(42.5 \%)$ patients sought attention within 24 hours of noticing symptoms of acute appendicitis.

\section{Time of delay among patients with complicated or uncomplicated acute appendicitis}

The mean prehospital delay was 27.68 hours with a median of 26 hours, while the mean in-hospital delay was 5.16 hours with a median of 5 hours. Most patients $(61.5 \%$; $\mathrm{n}=259$ ) were discharged with a diagnosis of uncomplicated acute appendicitis. Patients with complicated appendicitis had a significantly longer prehospital delay (27 vs 25 hours, $\mathrm{p}=0.002$ ) and total delay ( 33 vs 30 hours, $\mathrm{p}=0.002$ ). There was no significant difference in time of in-hospital delay between the two groups (table 1). 
Table 1 Time of delay among patients with complicated or uncomplicated acute appendicitis

\begin{tabular}{llll}
\hline $\begin{array}{l}\text { Time of delay } \\
\text { (hours) }\end{array}$ & $\begin{array}{l}\text { Uncomplicated } \\
\text { (n=259) }\end{array}$ & $\begin{array}{l}\text { Complicated } \\
(\mathbf{n = 1 6 2})\end{array}$ & P value \\
\hline $\begin{array}{l}\text { Prehospital, } \\
\text { median (IQR) }\end{array}$ & $25(18-31)$ & $27(23-32)$ & 0.002 \\
$\begin{array}{l}\text { In-hospital, } \\
\text { median (IQR) }\end{array}$ & $5(4-6)$ & $5(4-6)$ & 0.459 \\
\hline $\begin{array}{l}\text { Total, median (IQR) } \\
30(22-36)\end{array}$ & $33(28-38)$ & 0.002 \\
\hline
\end{tabular}

\section{Demographic characteristics of patients}

Table 2 shows the demographic characteristics of patients with acute appendicitis in two groups. The patients in the delay group were more likely to be aged $\geq 60$ years $(40.1 \%$ vs $26.8 \%, p=0.013)$ and to living alone $(30.2 \%$ vs $18.4 \%$, $\mathrm{p}=0.004$ ) than patients in the no delay group. A history of appendicitis among acquaintances may encourage patients to seek medical help when suffering abdominal pain $(36.3 \%$ vs $14.0 \%, \mathrm{p}<0.001$.). With respect to sex, marital status, education level, occupation, monthly income, place of residence, distance from home to hospital and insurance status, the differences among the participants with different prehospital delays were not statistically significant $(p>0.05)$.

\section{Prehospital delay by clinical variables}

The association between clinical status and prehospital delay is presented in table 3. Overall, migrating pain, fever, vomiting, diarrhoea, RLQ rebound tenderness, white blood cell count, neutrophil percentage, C-reactive protein, incarcerated by faecal stone, and night-time or daytime symptom onset had no significant association with the visit time of patients. However, those with severe pain were more likely to see the doctor within 24 hours compared with those with mild or moderate pain $(32.2 \%$ vs $21.8 \%, \mathrm{p}=0.013$ ). The symptoms of patients in the delay group were more likely to have occurred on a working day $(68.2 \%$ vs $55.3 \%$, $\mathrm{p}=0.008)$.

\section{Psychosocial factors of participants}

There was a significant difference in the distribution of EPQ personality traits and social support among patients in the two groups $(\mathrm{p}<0.05)$; the delayed patients had a larger proportion of unstable introverts and poor social support compared with the no delay patients. The results of the TCSQ showed no significant differences between the two groups on the positive coping dimensions, but the delay group had a significantly higher score on the negative coping dimension $(\mathrm{p}<0.05)$ (table 4$)$.

\section{Factors associated with prehospital delay}

In the logistic regression analyses, eight variables or subvariables were associated with prehospital delay $>24$ hours. As shown in table 5, patients $\geq 60$ years of age had 2.36 times the odds of delaying compared with patients $<40$ years of age (95\% CI 1.39 to $4.02 ; \mathrm{p}=0.002$ ). Additionally, patients who lived alone $(\mathrm{OR}=1.74,95 \%$ CI 1.02 to
2.97; $\mathrm{p}=0.042)$ had significantly higher odds of presentation delay than patients who lived with others. Having no history of appendicitis among acquaintances and having symptoms that occurred on a workday may delay patients' seeking medical help when suffering from acute appendicitis $(\mathrm{OR}=2.72,95 \% \mathrm{CI} 1.61$ to $4.60 ; \mathrm{p}<0.001$ and $\mathrm{OR}=1.72, \quad 95 \%$ CI 1.08 to $2.73 ; \mathrm{p}=0.021$, respectively). Those suffering from mild pain were more likely to see the doctor after more than 24 hours compared with those suffering from severe pain $(\mathrm{OR}=2.51,95 \% \mathrm{CI}$ 1.44 to $4.35 ; \mathrm{p}=0.001)$. With respect to EPQ personality traits, the odds for stable extroverts and unstable introverts were 0.51 times $(95 \%$ CI 0.27 to $0.97 ; \mathrm{p}=0.041)$ and 2.32 times (95\% CI 1.20 to 4.48 ; $\mathrm{p}=0.012$ ) the odds for transitional personality, respectively. Patients' poor social support and negative coping style were significantly associated with prehospital delay $(\mathrm{OR}=2.55,95 \% \mathrm{CI}$ 1.46 to $4.47 ; \mathrm{p}=0.001$ and $\mathrm{OR}=1.04,95 \%$ CI 1.01 to 1.06 ; $\mathrm{p}=0.002$, respectively).

\section{DISCUSSION}

In this investigation, only $179(42.5 \%)$ of the 421 patients with acute appendicitis were transferred to the hospital within 24 hours; the mean prehospital delay was 27.68 hours with a median of 26 hours, while the mean in-hospital delay was 5.16 hours with a median of 5 hours. No previous study had investigated the delay among Chinese patients with acute appendicitis; the present study is the first to reveal that patients in this southwestern city in China are facing a major problem in terms of presentation delays, consistent with the results of reports from abroad. ${ }^{12} 3233$ Because this research was not focused on the relationship between patient delay and complicated appendicitis, we simply compared the overall differences in delay between patients with complicated and uncomplicated appendicitis without adjusting for other variables that might predict increased odds of complicated appendicitis. However, the present study did find that patients with complicated appendicitis had a significantly longer time of prehospital delay ( 27 vs 25 hours, $\mathrm{p}=0.002$ ) and total delay ( 33 vs 30 hours, $\mathrm{p}=0.002$ ) but not in-hospital delay ( 5 vs 5 hours, $\mathrm{p}=0.459$ ), suggesting that the main factor associated with complicated appendicitis is prehospital presentation time, similar to most studies. ${ }^{7} 1634$ Therefore, it will be useful to determine and avoid the contributors that can cause prehospital delay in patients with acute appendicitis.

The factors associated with prehospital delay are numerous and include sociodemographic characteristics, clinical factors, cognitive factors and psychosocial factors. For each factor, different associations were found across different studies of different diseases. Sociodemographic characteristics play an important role in prehospital delay, especially in low-income and middle-income countries. Our analysis revealed that patients at more advanced ages ( $\geq 60$ years) were more likely to delay presentation, similar to studies of chronic or emergent diseases such 
Table 2 Demographic characteristics of patients $(n=421)$

\begin{tabular}{|c|c|c|c|c|}
\hline Demographic characteristics & Total $(n=421)$ & Delay $(n=242)$ & No delay $(n=179)$ & $P$ value \\
\hline Age (years), n (\%) & & & & 0.013 \\
\hline $18-39$ & $172(40.9)$ & $87(36.0)$ & $85(47.5)$ & \\
\hline $40-59$ & $104(24.7)$ & $58(23.9)$ & $46(25.7)$ & \\
\hline$\geq 60$ & $145(34.4)$ & $97(40.1)$ & $48(26.8)$ & \\
\hline Sex, n (\%) & & & & 0.921 \\
\hline Male & $216(51.3)$ & $125(51.7)$ & $91(50.8)$ & \\
\hline Female & $205(48.7)$ & $117(48.3)$ & $88(49.2)$ & \\
\hline Marital status, n (\%) & & & & 0.924 \\
\hline Unmarried & $57(13.5)$ & $34(14.0)$ & $23(12.8)$ & \\
\hline Married & $314(74.6)$ & $180(74.4)$ & $134(74.9)$ & \\
\hline Divorced/widowed & 50 (11.9) & $28(11.6)$ & $22(12.3)$ & \\
\hline Education level, n (\%) & & & & 0.869 \\
\hline No formal schooling & $74(17.6)$ & $43(17.8)$ & $31(17.3)$ & \\
\hline Primary or junior/middle school & $165(39.2)$ & $97(40.1)$ & $68(38.0)$ & \\
\hline High school and above & $182(43.2)$ & $102(42.1)$ & $80(44.7)$ & \\
\hline Occupation, n (\%) & & & & 0.400 \\
\hline Unemployed & 98 (23.3) & $52(21.5)$ & $46(25.7)$ & \\
\hline Physical labour & $170(40.4)$ & $104(43.0)$ & $66(36.9)$ & \\
\hline Non-physical labour & $153(36.3)$ & $86(35.5)$ & $67(37.4)$ & \\
\hline Monthly income, n (\%) & & & & 0.308 \\
\hline$<¥ 2000$ & $125(29.7)$ & 65 (26.9) & $60(33.5)$ & \\
\hline$¥ 2000-5000$ & $166(39.4)$ & $101(41.7)$ & $65(36.3)$ & \\
\hline$>¥ 5000$ & $130(30.9)$ & $76(31.4)$ & $54(30.2)$ & \\
\hline Place of residence, $\mathrm{n}(\%)$ & & & & 0.311 \\
\hline Rural & $227(53.9)$ & $125(51.7)$ & $102(57.0)$ & \\
\hline Town & $99(23.5)$ & $56(23.1)$ & $43(24.0)$ & \\
\hline City & $95(22.6)$ & $61(25.2)$ & $34(19.0)$ & \\
\hline Living alone or with others, $\mathrm{n}(\%)$ & & & & 0.004 \\
\hline Living alone & $106(25.2)$ & $73(30.2)$ & $33(18.4)$ & \\
\hline Living with others & $315(74.8)$ & $169(69.8)$ & $146(81.6)$ & \\
\hline $\begin{array}{l}\text { Distance from home to hospital (km), } \\
\text { median (IQR) }\end{array}$ & $6(5-7)$ & $6(5-7)$ & $6(5-7)$ & 0.432 \\
\hline Insurance status, n (\%) & & & & 0.248 \\
\hline No & $19(4.5)$ & $9(3.7)$ & $10(5.6)$ & \\
\hline Yes & $402(95.5)$ & $233(96.3)$ & $169(94.4)$ & \\
\hline $\begin{array}{l}\text { History of appendicitis among } \\
\text { acquaintances, } \mathrm{n}(\%)\end{array}$ & & & & $<0.001$ \\
\hline No & $322(76.5)$ & $208(86.0)$ & $114(63.7)$ & \\
\hline Yes & $99(23.5)$ & $34(14.0)$ & 65 (36.3) & \\
\hline
\end{tabular}

as tumour and stroke. ${ }^{35-37}$ However, contrary to these studies ${ }^{38-40}$ no associations between prehospital delay and economic factors, sex, marital status, education level, occupation, place of residence, distance from home to hospital or insurance status were found in our study. One way that this can be explained is that with the popularisation of insurance, more convenient transport and the development of improved diagnosis and treatment technology in hospitals, seeking medical help for acute appendicitis is no longer a complicated, expensive and time-consuming process.

Regarding clinical characteristics, only patients with severe pain were less likely to have a prehospital delay compared with patients with mild or moderate pain. In 
Table 3 Clinical characteristics of patients $(n=421)$

\begin{tabular}{|c|c|c|c|c|}
\hline Clinical variables & Total $(n=421)$ & Delay $(n=242)$ & No delay $(n=179)$ & $P$ value \\
\hline Migrating pain, n (\%) & & & & 0.368 \\
\hline No & $108(25.7)$ & $58(24.0)$ & $50(27.9)$ & \\
\hline Yes & $313(74.3)$ & $184(76.0)$ & $129(72.1)$ & \\
\hline Fever, n (\%) & & & & 0.417 \\
\hline No & $260(61.8)$ & $145(59.9)$ & $115(64.2)$ & \\
\hline Yes & $161(38.2)$ & $97(40.1)$ & $64(35.8)$ & \\
\hline Vomiting, n (\%) & & & & 0.394 \\
\hline No & $129(30.6)$ & $70(28.9)$ & $59(33.0)$ & \\
\hline Yes & $292(69.4)$ & $172(71.1)$ & $120(67.0)$ & \\
\hline Diarrhoea, n (\%) & & & & 0.425 \\
\hline No & $352(83.6)$ & 199 (82.2) & $153(85.6)$ & \\
\hline Yes & $69(16.4)$ & $43(17.8)$ & $26(14.5)$ & \\
\hline RLQ rebound tenderness, $\mathrm{n}(\%)$ & & & & 0.400 \\
\hline No & 209 (49.6) & $123(50.8)$ & $86(48.0)$ & \\
\hline Yes & $212(50.4)$ & 119 (49.2) & $93(52.0)$ & \\
\hline $\begin{array}{l}\text { White blood cell count }\left(\times 10^{9} / \mathrm{L}\right) \text {, } \\
\text { median (IQR) }\end{array}$ & $13.5(11.1-15.9)$ & $13.9(11.3-15.7)$ & $13.1(10.4-16.0)$ & 0.224 \\
\hline $\begin{array}{l}\text { Neutrophil percentage (\%), } \\
\text { means } \pm \text { SD }\end{array}$ & $81.5 \pm 9.1$ & $81.0 \pm 10.1$ & $82.2 \pm 7.6$ & 0.192 \\
\hline C-reactive protein, median (IQR) & $7.32(5.629 .04)$ & $7.22(5.64-8.85)$ & $7.64(5.62-9.22)$ & 0.705 \\
\hline Incarcerated by faecal stone, $\mathrm{n}(\%)$ & & & & 0.196 \\
\hline No & $326(77.4)$ & $193(79.8)$ & $133(74.3)$ & \\
\hline Yes & $95(22.6)$ & $49(20.2)$ & $46(25.7)$ & \\
\hline $\begin{array}{l}\text { Symptoms occurred on a workday or } \\
\text { weekend, } \mathrm{n}(\%)\end{array}$ & & & & 0.008 \\
\hline Workday & $264(62.7)$ & $165(68.2)$ & $99(55.3)$ & \\
\hline Weekend & $157(37.3)$ & $77(31.8)$ & $80(44.7)$ & \\
\hline $\begin{array}{l}\text { Night-time or daytime symptom } \\
\text { onset, } n(\%)\end{array}$ & & & & 0.248 \\
\hline Night-time & $214(50.8)$ & $117(48.3)$ & $97(54.2)$ & \\
\hline Daytime & $207(49.2)$ & $125(51.7)$ & $82(45.8)$ & \\
\hline Intensity of pain, $\mathrm{n}(\%)$ & & & & 0.013 \\
\hline Mild & $220(52.3)$ & $121(50.0)$ & $99(55.3)$ & \\
\hline Moderate & $84(20.0)$ & $43(17.8)$ & $41(22.9)$ & \\
\hline Severe & 117 (27.7) & 78 (32.2) & $39(21.8)$ & \\
\hline
\end{tabular}

RLQ, right lower quadrant.

addition, symptoms occurring on a working day was one of the barriers to seeking medical help among patients with acute appendicitis. Some studies reported a positive association between symptoms and/or signs of disease and patient delay. ${ }^{41}{ }^{42}$ However, no difference in prehospital delay was found between patients with different clinical characteristics, including migrating pain, fever, vomiting, diarrhoea, RLQ rebound tenderness, white blood cell count, neutrophil percentage, $\mathrm{C}$ reactive protein and incarcerated faecal stone in the present study. Although an uncommon clinical presentation may increase the difficulty of diagnosis for the doctor, which may cause diagnostic delays, it is not an important factor for patients in deciding whether or not to see a doctor.

Patients' interpretation of symptoms and knowledge of the disease have been shown to be strongly associated with patient delays in other quantitative studies of cancer and stroke ${ }^{43-45}$ In the present study, the patients who had experienced the process of diagnosis and treatment of acute appendicitis in their acquaintances often arrived at the emergency department or hospital earlier than other patients. Knowledge of acute appendicitis gleaned 


\begin{tabular}{|c|c|c|c|c|}
\hline Psychosocial factors & Total $(n=421)$ & Delay $(n=242)$ & No delay $(n=179)$ & $P$ value \\
\hline EPQ personality traits, $n(\%)$ & & & & $<0.001$ \\
\hline Transitional personality & $99(23.5)$ & $56(23.1)$ & $43(24.0)$ & \\
\hline Stable introverts & 77 (18.3) & $42(17.4)$ & 35 (19.6) & \\
\hline Stable extroverts & $95(22.5)$ & $40(16.5)$ & $55(30.7)$ & \\
\hline Unstable extroverts & $44(10.5)$ & $24(9.9)$ & $20(11.2)$ & \\
\hline Unstable introverts & $106(25.2)$ & 80 (33.1) & $26(14.5)$ & \\
\hline Perceived social support scale, $\mathrm{n}(\%)$ & & & & 0.002 \\
\hline Good & $180(42.8)$ & $91(37.6)$ & $89(49.7)$ & \\
\hline Moderate & $118(28.0)$ & 64 (26.4) & $54(30.2)$ & \\
\hline Poor & $123(29.2)$ & $87(36.0)$ & $36(20.1)$ & \\
\hline \multicolumn{5}{|l|}{ Trait coping style, median (IQR) } \\
\hline Positive coping & $38(28-41)$ & $38(28-41)$ & $38(24-41)$ & 0.134 \\
\hline Negative coping & $28(21-39)$ & $34(22-39)$ & $24(19-38)$ & $<0.001$ \\
\hline
\end{tabular}

$E P Q$, Eysenck Personality Questionnaire .

from this experience increased patients' awareness that they had an acute appendicitis rather than acute gastroenteritis when the initial symptoms occurred.

Previous studies found that the personality traits of extraversion and neuroticism were significantly associated with cancer screening attendance. ${ }^{46-48}$ This study demonstrates that personality traits influence prehospital delay. The 'unstable introvert' group waited the longest waiting before deciding to see a doctor. Neurotic personalities have lower levels of self-efficacy that are likely to be unhelpful and lead to avoidance behaviour when facing trouble. Extroverts have higher self-efficacy and may be more motivated to participate in therapy. On the other hand, introverts may be more unwilling to participate due to lack of motivation. ${ }^{49}$ Extroversion has also been demonstrated to be associated with a higher pain tolerance, greater use of active coping mechanisms and lower perceived intensity of pain. ${ }^{50}$

Coping refers to one's ability to change cognitive and behavioural efforts constantly, to manage specific external or internal demands that are appraised as taxing or exceeding the resources of the person; this concept originated from theories of self-defence. ${ }^{51}$ In this study, there were no significant differences between the two groups in the positive coping dimensions of the TCSQ; however, the delay group had scores on the negative coping dimension that were higher than the scores of the no delay group, indicating that these patients tended to adopt a negative and immature avoidant coping mode after noticing symptoms of acute appendicitis.

Regarding social support, we found that patients in the delay group had significantly lower social support and were likely to live alone compared with patients in the no delay group. A study reported that patients with breast cancer who lacked social support from family members and spouses were more likely to delay. ${ }^{43}$ Another study conducted in Mexico in 2011 reported that social support is crucial for materialisation of the initial contact as well as for community care.$^{52}$ Social support was defined as the perception and actuality that one is cared for, has assistance available from other people (spouse, relatives and friends) and that one is part of a supportive social network. ${ }^{53}$ Social support is considered to promote biological or behavioural adaptations under conditions of stress. This may result in better treatment compliance and the adoption of better health behaviours, which will generally exert positive effects on overall physical condition. ${ }^{54}$ Several studies have also described how the patient's concealment of symptoms may influence the delay in seeking medical, while discussing them with friends and family can facilitate the decision to seek medical advice. ${ }^{55}$

Our study had some advantages. Even though there were many studies of the relationship between delay and clinical outcomes, we were the first to test the association between psychosocial factors and prehospital delay in patients with acute appendicitis. Numerous factors may affect the decision of patients to see doctor, and the factors can confound each other; therefore, we considered sociodemographic characteristics, clinical factors, cognitive factors and psychosocial factors. We entered into the binary logistics model variables that, in the initial analyses, were significantly different between the two groups at an alpha level of 0.05 . After adjusting for other variables, the variables retained in the model can predict the increased odds of prehospital delay. This line of thinking may also be useful to extend to other emergency surgery conditions indirectly, because in the absence of surgical care, case-fatality rates are high for common, easily treatable conditions; this may result not only from economic problems, especially in low-income and middle-income countries ${ }^{56}$ but also from psychosocial factors that are confronted globally. 
Table 5 The results of logistic regression analysis on prehospital delay

\begin{tabular}{|c|c|c|c|c|}
\hline Psychosocial factors & Delay $(n=242)$ & No delay $(n=179)$ & OR $(95 \% \mathrm{Cl})$ & $P$ value \\
\hline Age (years), n (\%) & & & & 0.013 \\
\hline $18-39$ & $87(36.0)$ & $85(47.5)$ & Reference & \\
\hline $40-59$ & $58(23.9)$ & $46(25.7)$ & 1.31 (0.74 to 2.32$)$ & 0.359 \\
\hline$\geq 60$ & $97(40.1)$ & $48(26.8)$ & 2.36 (1.39 to 4.02$)$ & 0.002 \\
\hline Living alone or with others, $\mathrm{n}(\%)$ & & & & 0.004 \\
\hline Living with others & $169(69.8)$ & $146(81.6)$ & Reference & \\
\hline Living alone & $73(30.2)$ & $33(18.4)$ & 1.74 (1.02 to 2.97$)$ & 0.042 \\
\hline $\begin{array}{l}\text { History of appendicitis among } \\
\text { acquaintances, } \mathrm{n}(\%)\end{array}$ & & & & $<0.001$ \\
\hline Yes & $34(14.0)$ & $65(36.3)$ & Reference & \\
\hline No & $208(86.0)$ & $114(63.7)$ & 2.72 (1.61 to 4.60$)$ & $<0.001$ \\
\hline Symptoms occurred on a workday or $\mathrm{n}$ & kend, n (\%) & & & 0.008 \\
\hline Weekend & $77(31.8)$ & $80(44.7)$ & Reference & \\
\hline Workday & $165(68.2)$ & 99 (55.3) & 1.72 (1.08 to 2.73$)$ & 0.021 \\
\hline Intensity of pain, $\mathrm{n}(\%)$ & & & & 0.013 \\
\hline Severe & $78(32.2)$ & $39(21.8)$ & Reference & \\
\hline Moderate & $43(17.8)$ & $41(22.9)$ & 0.83 (0.38 to 1.79$)$ & 0.631 \\
\hline Mild & $121(50.0)$ & 99 (55.3) & 2.51 (1.44 to 4.35$)$ & 0.001 \\
\hline EPQ personality traits, $n(\%)$ & & & & $<0.001$ \\
\hline Transitional personality & $56(23.1)$ & $43(24.0)$ & Reference & \\
\hline Stable introverts & $42(17.4)$ & $35(19.6)$ & $0.92(0.47$ to 1.81$)$ & 0.809 \\
\hline Stable extroverts & $40(16.5)$ & $55(30.7)$ & 0.51 (0.27 to 0.97$)$ & 0.041 \\
\hline Unstable extroverts & $24(9.9)$ & $20(11.2)$ & $0.74(0.33$ to 1.66$)$ & 0.466 \\
\hline Unstable introverts & $80(33.1)$ & $26(14.5)$ & $2.32(1.20$ to 4.48$)$ & 0.012 \\
\hline Perceived Social Support Scale, n (\%) & & & & 0.002 \\
\hline Good & $91(37.6)$ & $89(49.7)$ & Reference & \\
\hline Moderate & $64(26.4)$ & $54(30.2)$ & 1.54 (0.77 to 3.05$)$ & 0.219 \\
\hline Poor & $87(36.0)$ & $36(20.1)$ & 2.55 (1.46 to 4.47$)$ & 0.001 \\
\hline Negative coping style, median (IQR) & $34(22-39)$ & $24(19-38)$ & 1.04 (1.01 to 1.06$)$ & 0.002 \\
\hline
\end{tabular}

$E P Q$, Eysenck Personality Questionnaire.

However, several limitations should be considered when interpreting our results. First, we observed only a temporal relationship between psychosocial factors and prehospital delay in patients with acute appendicitis. Second, the number of analysed participants was 421 , which was a small proportion of the number of residents in our city. Third, we used a questionnaire to determine the psychosocial factors; participants' answers were subject to mistakes in recollection and other errors. Fourth, the present study was conducted in a single centre; thus, it is not known whether the present findings apply to other populations with different economic and cultural conditions.

\section{CONCLUSION}

In summary, prehospital delay for acute appendicitis was common in this southwestern city of China. The results suggest that the prehospital delay may be attributed to some psychosocial factors such as older age, living alone, a lack of knowledge of the disease, low social support, an unstable introvert personality trait and negative coping style. The intensity of pain and symptoms occurring on a workday are the most important clinical factors affecting delay in presentation of acute appendicitis. We believe that a better understanding of the association between psychosocial factors and prehospital delay can help identify patients with acute appendicitis at risk of prehospital delay and lead to the establishment of an effective campaign to promote hospital visits when symptoms are noticed.

Acknowledgements The authors thank all the participants involved in the survey. The authors would also like to thank the Health and Family Planning Commission of Mianyang City for their support. 
Contributors $\mathrm{JL}$ and $\mathrm{RX}$ designed the study. $\mathrm{JL}$ was directly involved in the full implementation of this study and was a major contributor to the writing of the manuscript. JL, RX, DH and YZ were jointly involved in the diagnosis and treatment of patients. JL, YZ, XW and TG collected and analysed the data. All authors read and approved the final manuscript.

Funding The authors have not declared a specific grant for this research from any funding agency in the public, commercial or not-for-profit sectors.

Competing interests None declared.

Patient consent for publication Obtained.

Ethics approval Ethical approval wasobtained from the ethical committee of the Third Hospital of Mianyang. Thestudy was performed in accordance with the Declaration of Helsinki.

Provenance and peer review Not commissioned; externally peer reviewed.

Data sharing statement № additional data are available.

Open access This is an open access article distributed in accordance with the Creative Commons Attribution Non Commercial (CC BY-NC 4.0) license, which permits others to distribute, remix, adapt, build upon this work non-commercially, and license their derivative works on different terms, provided the original work is properly cited, appropriate credit is given, any changes made indicated, and the use is non-commercial. See: http://creativecommons.org/licenses/by-nc/4.0/.

\section{REFERENCES}

1. Anderson JE, Bickler SW, Chang DC, et al. Examining a common disease with unknown etiology: trends in epidemiology and surgical management of appendicitis in California, 1995-2009. World J Surg 2012;36:2787-94.

2. Cueto J, D'Allemagne B, Vázquez-Frias JA, et al. Morbidity of laparoscopic surgery for complicated appendicitis: an international study. Surg Endosc 2006;20:717-20.

3. Yaghoubian A, de Virgilio C, Lee SL. Appendicitis outcomes are better at resident teaching institutions: a multi-institutional analysis. Am J Surg 2010;200:810-3.

4. Gandy RC, Truskett PG, Wong SW, et al. Outcomes of appendicectomy in an acute care surgery model. Med $\mathrm{J}$ Aust 2010;193:281-4.

5. Berry J, Malt RA. Appendicitis near its centenary. Ann Surg 1984;200:567-75.

6. Fitz RH. Perforating inflammation of the vermiform appendix: with special reference to its early diagnosis and treatment. Am J Med Sci 1886;92:321-46.

7. Abou-Nukta F, Bakhos C, Arroyo K, et al. Effects of delaying appendectomy for acute appendicitis for 12 to 24 hours. Arch Surg 2006;141:504-6.

8. Eastridge BJ, Hamilton EC, O'Keefe GE, et al. Effect of sleep deprivation on the performance of simulated laparoscopic surgical skill. Am J Surg 2003;186:169-74.

9. Andersson R, Hugander A, Thulin A, et al. Indications for operation in suspected appendicitis and incidence of perforation. BMJ 1994;308:107-10.

10. Ciani S, Chuaqui B. Histological features of resolving acute, non-complicated phlegmonous appendicitis. Pathol Res Pract 2000;196:89-93.

11. Stahlfeld K, Hower J, Homitsky S, et al. Is acute appendicitis a surgical emergency? Am Surg 2007;73:626-9.

12. Kearney D, Cahill RA, O'Brien E, et al. Influence of delays on perforation risk in adults with acute appendicitis. Dis Colon Rectum 2008;51:1823-7.

13. Ingraham AM, Cohen ME, Bilimoria KY, et al. Effect of delay to operation on outcomes in adults with acute appendicitis. Arch Surg 2010;145:886-92.

14. Andersson RE. Does delay of diagnosis and treatment in appendicitis cause perforation? World J Surg 2016;40:1315-7.

15. Temple CL, Huchcroft SA, Temple WJ. The natural history of appendicitis in adults. A prospective study. Ann Surg 1995;221:278-81.

16. Bickell NA, Aufses AH, Rojas M, et al. How time affects the risk of rupture in appendicitis. J Am Coll Surg 2006;202:401-6.

17. Teixeira PG, Sivrikoz E, Inaba K, et al. Appendectomy timing: waiting until the next morning increases the risk of surgical site infections. Ann Surg 2012;256:538-43.

18. Eldar S, Nash E, Sabo E, et al. Delay of surgery in acute appendicitis. Am J Surg 1997;173:194-8.
19. Blomqvist $P G$, Andersson RE, Granath F, et al. Mortality after appendectomy in Sweden, 1987-1996. Ann Surg 2001;233:455-60.

20. Farrar JT, Young JP, LaMoreaux L, et al. Clinical importance of changes in chronic pain intensity measured on an 11-point numerical pain rating scale. Pain 2001;94:149-58.

21. Qian M, Wu G, Zhu R, et al. Development of the revised Eysenck Personality Questionnaire Short Scale for Chinese (EPQ-RSC). Acta Psychologica Sinica 2000;32:317-23.

22. Zhang Z, Shi Z, Wang L, et al. Post-traumatic stress disorder, anxiety and depression among the elderly: a survey of the hardhit areas a year after the Wenchuan earthquake. Stress Health 2012;28:61-8.

23. Cui Y, Tian SS, Qiao N, et al. Associations of individual-related and job-related risk factors with nonfatal occupational injury in the coal workers of Shanxi province: a cross-sectional study. PLoS One 2015;10:e0134367.

24. Zhang ZJ. Handbook of behavioral medicine scales. Jining: Chinese Medicine Electronic Audio and Video Publishing House, 2005:36-8.

25. Zimet GD, Dahlem NW, Zimet SG, et al. The multidimensional scale of perceived social support. J Pers Assess 1988;52:30-41.

26. Canty-Mitchell J, Zimet GD. Psychometric properties of the multidimensional scale of perceived social support in urban adolescents. Am J Community Psychol 2000;28:391-400.

27. Du B, Ma X, Ou X, et al. The prevalence of posttraumatic stress in adolescents eight years after the Wenchuan earthquake. Psychiatry Res 2018;262:262-9.

28. Zeng QX, Hy H, Cm X, et al. Characteristics of post-traumatic growth and their association with social support and coping style in patients with acute myocardial infarction. Acta Academiae Medicinae Militaris Tertiae 2018;40:176-82.

29. Du J, Zhang D, Yin Y, et al. The personality and psychological stress predict major adverse cardiovascular events in patients with coronary heart disease after percutaneous coronary intervention for five years. Medicine 2016;95:e3364.

30. Zhou J, Yang Y, Qiu X, et al. Relationship between anxiety and burnout among chinese physicians: a moderated mediation model. PLoS One 2016;11:e0157013.

31. Di Saverio S, Birindelli A, Kelly MD, et al. WSES Jerusalem guidelines for diagnosis and treatment of acute appendicitis. World J Emerg Surg 2016;11:34.

32. Saar S, Talving P, Laos J, et al. Delay between onset of symptoms and surgery in acute appendicitis increases perioperative morbidity: a prospective study. World J Surg 2016;40:1308-14.

33. Sadot E, Wasserberg N, Shapiro R, et al. Acute appendicitis in the twenty-first century: should we modify the management protocol? $J$ Gastrointest Surg 2013;17:1462-70.

34. Ditillo MF, Dziura JD, Rabinovici R. Is it safe to delay appendectomy in adults with acute appendicitis? Ann Surg 2006;244:656-60.

35. Shen SC, Hung YC, Kung PT, et al. Factors involved in the delay of treatment initiation for cervical cancer patients: A nationwide population-based study. Medicine 2016;95:e4568.

36. Germann N, Haie-Meder C, Morice P, et al. Management and clinical outcomes of pregnant patients with invasive cervical cancer. Ann Oncol 2005;16:397-402.

37. Faiz KW, Sundseth A, Thommessen B, et al. Prehospital delay in acute stroke and TIA. Emerg Med J 2013;30:669-74.

38. Lin JH, Zhang SM, Manson JE. Predicting adherence to tamoxifen for breast cancer adjuvant therapy and prevention. Cancer Prev Res 2011;4:1360-5.

39. Arndt V, Stürmer T, Stegmaier C, et al. Patient delay and stage of diagnosis among breast cancer patients in Germany -- a population based study. Br J Cancer 2002;86:1034-40.

40. Dianatinasab M, Fararouei M, Mohammadianpanah M, et al. Impact of social and clinical factors on diagnostic delay of breast cancer: $A$ Cross-sectional Study. Medicine 2016;95:e4704.

41. Buchman TG, Zuidema GD. Reasons for delay of the diagnosis of acute appendicitis. Surg Gynecol Obstet 1984;158:260-6.

42. Choi JY, Ryoo E, Jo JH, et al. Risk factors of delayed diagnosis of acute appendicitis in children: for early detection of acute appendicitis. Korean J Pediatr 2016;59:368-73.

43. Odongo J, Makumbi T, Kalungi S, et al. Patient delay factors in women presenting with breast cancer in a low income country. BMC Res Notes 2015;8:467.

44. Ramirez AJ, Westcombe AM, Burgess CC, et al. Factors predicting delayed presentation of symptomatic breast cancer: a systematic review. Lancet 1999;353:1127-31.

45. Inatomi $Y$, Yonehara T, Hashimoto $Y$, et al. Pre-hospital delay in the use of intravenous rt-PA for acute ischemic stroke in Japan. J Neurol Sci 2008;270:127-32.

46. Chaitchik S, Kreitler S. Induced versus spontaneous attendance of breast-screening tests by women. J Cancer Educ 1991;6:43-53. 
47. Siegler IC, Feaganes JR, Rimer BK. Predictors of adoption of mammography in women under age 50. Health Psychol 1995;14:274-8.

48. Arai S, Nakaya N, Kakizaki M, et al. Personality and gastric cancer screening attendance: a cross-sectional analysis from the Miyagi Cohort Study. J Epidemiol 2009;19:34-40.

49. Ramaesh R, Jenkins P, Macdonald D, et al. Personality, function and satisfaction in patients undergoing total hip or knee replacement. $J$ Orthop Sci 2014;19:275-81.

50. Zimmerman BJ. Self-efficacy: an essential motive to learn. Contemp Educ Psychol 2000;25:82-91.

51. Xu L, Pan Q, Lin R. Prevalence rate and influencing factors of preoperative anxiety and depression in gastric cancer patients in China: Preliminary study. J Int Med Res 2016;44:377-88.
52. Gakwaya A, Kigula-Mugambe JB, Kavuma A, et al. Cancer of the breast: 5-year survival in a tertiary hospital in Uganda. Br J Cancer 2008;99:63-7.

53. Cooke BD, Rossmann MM, McCubbin $\mathrm{HI}$, et al. Examining the definition and assessment of social support: a resource for individuals and families. Fam Relat 1988;37:211-6.

54. Wang C, Fan G, Xu R, et al. A case-control study of the association between psychosocial factors and the occurrence of laryngeal cancer. Mol Clin Oncol 2017;7:443-8.

55. Burgess C, Hunter MS, Ramirez AJ. A qualitative study of delay among women reporting symptoms of breast cancer. Br J Gen Pract 2001;51:967-71.

56. Meara JG, Leather AJ, Hagander L, et al. Global Surgery 2030: evidence and solutions for achieving health, welfare, and economic development. Lancet 2015;386:569-624. 